\title{
GAMBARAN TINGKAT DEPRESI PADA WARGA KORBAN BANJIR BANDANG DI KELURAHAN TIKALA ARES KOTA MANADO
}

\author{
${ }^{1}$ Dion Tulalessy \\ ${ }^{2}$ Anita E. Dundu \\ ${ }^{2}$ Herdy Munayang \\ ${ }^{1}$ Kandidat skripsi Fakultas Kedokteran Universitas Sam Ratulangi \\ ${ }^{2}$ Bagian Psikiatri Fakultas Kedokteran Universitas Sam Ratulangi \\ Email: dion_143@ymail.com
}

\begin{abstract}
Depression is one of the major mental health problems today. WHO predicts that in 2020 depression will be the second highest cause of death after heart attack. Generally, the cause of depression is divided into three factors, inter alia biological factors. The Learned helplessness theory explains the causes of depression and defines that depression occurs because of painful events that cannot be controlled by someone. Painful events also can be caused by natural disasters, one of them was flood. This was a descriptive qualitative study with a cross-sectional design by using a sociodemographic questionnaire and be assessed by using the Beck Depression Inventory questionnaire. The results showed that there were 3 respondents (10\%) without depression; 8 respondents (26.7\%) with mild depressive disorders; 15 respondets (50\%) with moderate depressive disorders; and 4 respondents (13.3\%) with major depressive disorders.
\end{abstract}

Keywords: depression, flood victims, Beck Depression Inventory.

\begin{abstract}
Abstrak: Depresi merupakan salah satu masalah kesehatan mental utama saat ini, WHO memprediksikan bahwa pada tahun 2020 nanti depresi akan menjadi penyebab kedua terbesar kematian setelah serangan jantung. Teori Learned Helplessness menjelaskan mengenai penyebab depresi dan mennyatakan bahwa gangguan depresi muncul akibat peristiwa menyakitkan yang tidak dapat dikontrol seseorang. Peristiwa yang menyakitkan juga bisa disebabkan oleh faktor bencana alam, salah satunya ialah banjir. Penelitian ini menggunakan metode deskriptif dengan desain potong-lintang, kuesioner sosiodemografik yang dinilai dengan kuesioner Beck Depression Inventory. Hasil penelitian memperlihatkan responden yang tidak mengalami gangguan depresi sebanyak 3 orang (10,0\%); gangguan depresi ringan sebanyak 8 orang (26,7\%); gangguan depresi sedang sebanyak 15 orang (50\%); dan gangguan depresi berat sebanyak 4 orang (13,3\%).
\end{abstract}

Kata kunci: depresi, korban banjir bandang, Beck depression inventory

Pengertian sehat saat ini masih dipertentangkan para ahli dan belum ada kata sepakat dari para ahli kesehatan maupun tokoh masyarakat dunia. World Health Organization (WHO) mendefinisikan secara universal pengertian sehat adalah suatu keadaan kondisi fisik, mental, dan kesejahteraan sosial yang merupakan satu kesatuan dan bukan hanya bebas dari penyakit atau kecacatan. ${ }^{1}$ Depresi merupakan salah satu masalah kesehatan mental utama saat ini, WHO memprediksikan bahwa pada tahun 2020 nanti depresi akan menjadi penyebab kedua terbesar kecacatan dan kematian setelah serangan jantung. ${ }^{2}$ 
Depresi merupakan keluhan umum yang sering dialami masyarakat. Orang yang mengalami depresi umumnya mengalami gangguan-gangguan yang meliputi emosi, motivasi, fungsional, dan tingkah laku serta kognisi bercirikan ketidakberdayaan yang berlebihan. ${ }^{3}$

Pada umumnya penyebab gangguan depresi terbagi atas 3 faktor, yaitu faktor biologis, faktor genetik dan faktor psikososial. Ada berapa teori yang menjelaskan mengenai penyebab depresi, salah satunya yaitu teori Learned Helplessness. Teori ini mengatakan bahwa gangguan depresi muncul akibat peristiwa menyakitkan yang tidak dapat dikontrol seseorang. Peristiwa yang menyakitkan tersebut biasanya diperoleh dari pengalaman hidup yang tidak menyenangkan dan traumatik. ${ }^{4}$

Peristiwa yang menyakitkan juga bisa disebabkan oleh faktor bencana alam, salah satunya adalah banjir. Salah satu jenis banjir yang sering terjadi adalah banjir bandang. Perbedaan banjir bandang dengan banjir yang umum terjadi adalah intensitas waktu yang diperlukan air untuk menutupi daratan kering. ${ }^{5}$

Banjir bandang merupakan fenomena alam yang cukup sering terjadi di Indonesia. Salah satu banjir bandang di Indonesia khususnya pada kabupaten Jember 8 tahun yang lalu, melaporkan dari 1333 korban sebanyak 44\% mengalami gangguan depresi, $30 \%$ mengalami gangguan kecemasan, dan adapun juga ditemukan korban yang mengalami gangguan stress pasca trauma, akibat banjir bandang pada kabupaten Jamber. ${ }^{6}$

Penelitian ini bertujuan untuk mendapatkan gambaran tingkat depresi korban pasca banjir bandang di salah satu wilayah terjadinya banjir bandang di kota Manado mengingat banyaknya kerugian dan kerusakan yang dialami korban.

\section{METODE PENELITIAN}

Penelitian yang akan dilakukan adalah penelitian deskriptif kuantitatif dengan pendekatan cross - sectional study.
Populasi penelitian ialah warga daerah tikala ares lingkungan 3. Cara pemilihan sampel menggunakan cara purposiv sampling, yaitu dimana pengambilan sampel secara sengaja sesuai dengan persyaratan sampel yang diperlukan. Jumlah sampel yang memenihi kriteria inklusi dan ekslusi ialah berjumlah 30 responden. Pengumpulan data menggunakan kuesioner sosiodemografik dan BDI II.

\section{HASIL PENELITIAN \\ Data demografi responden}

Berdasarkan hasil penelitian yang dilakukan terhadap 30 responden didapatkan perempuan sebanyak 21 orang (70,0\%) sedangkan yang memiliki anak lelaki sebanyak 9 orang (30,0\%). Responden paling banyak terlibat dalam penelitian ialah yang dengan kategori usia 26-35 tahun sebanyak 9 orang (30,0\%). Responden paling banyak berpendidikan akhir SMA/SLTA yaitu 22 orang (73,3\%). Mayoritas responden yang telibat dalam penelitian beragama Kristen sebanyak 21 orang (70\%). Mayoritas responden yang terlibat dalam penelitian ialah responden yang tidak bekerja sebanyak 17 orang (56,7\%).

Berdasarkan hasil penelitian didapatkan bahwa korban banjir bandang paling banyak mengalami depresi sedang sebanyak 15 orang (50,0\%); depresi ringan sebanyak 8 orang (26,7\%); dan depresi berat sebanyak 4 orang (13,3\%). Jumlah korban banjir yang tidak mengalami depresi sebanyak 3 orang (10,0 \%).

Tabel 1. Distribusi frekuensi karakteristik demografi korban banjir bandang.

\begin{tabular}{lcc}
\hline Karakteristik Responden & (n) & $(\%)$ \\
\hline Jenis Kelamin & & \\
Perempuan & 21 & 70 \\
Laki-laki & 9 & 30 \\
Umur & & \\
17-25 tahun & 2 & 6,7 \\
26-35 tahun & 9 & 30,0 \\
36-45 tahun & 6 & 20,0 \\
46-55 tahun & 5 & 16,7 \\
\hline
\end{tabular}




\begin{tabular}{lcc}
\hline 56-65 tahun & 8 & 26,7 \\
Pendidikan Terakhir & & \\
SD & 2 & 6,7 \\
SMP/SLTP & 6 & 20,0 \\
SMA/SLTA & 22 & 73,3 \\
Agama & & \\
Kristen & 21 & 70,0 \\
Islam & 6 & 20,0 \\
Katolik & 3 & 10,0 \\
Budha & 0 & 0,0 \\
Hindu & 0 & 0,0 \\
Konghuchu & 0 & 0,0 \\
Pekerjaan & & \\
Bekerja & 13 & 43,3 \\
Tidak Bekerja & 17 & 56,7 \\
Daerah & & \\
Manado & 20 & 66,7 \\
Sangihe & 4 & 13,3 \\
Gorontalo & 2 & 6,7 \\
Cina & 4 & 13,3 \\
Jawa & 0 & 0,0 \\
\hline
\end{tabular}

\section{Data tingkat depresi responden}

Tabel 2. Distribusi frekuansi tingkat depresi responden

\begin{tabular}{ccc}
\hline $\begin{array}{c}\text { Tingkat Depresi } \\
\text { Responden }\end{array}$ & Frekuensi & $\begin{array}{c}\text { Persentase } \\
(\%)\end{array}$ \\
\hline Normal & 3 & 10,0 \\
Ringan & 8 & 26,7 \\
Sedang & 15 & 50,0 \\
Berat & 4 & 13,3 \\
Total & 30 & 100 \\
\hline
\end{tabular}

\section{BAHASAN}

\section{Karakteristik Responden}

Jenis kelamin perempuan lebih banyak dibandingkan dengan jenis kelamin lelaki, terdapat 21 jenis kelamin perempuan (70,0\%), sedangkan laki-laki jumlahnya hanya 9 orang $(30,0 \%)$, dan dari pengolahan data menunjukan bahwa paling banyak responden perempuan mengalami depresi sedang 14 orang (46,7\%) sedangkan responden lelaki mengalami depresi ringan sebanyak 7 orang (23,3\%).

Pada epidemiologi juga menjelaskan bahwa perempuan dua kali lipat lebih besar mengalami depresi dibanding lelaki. Diduga adanya perbedaan stresor psikososial antara lelaki dan perempuan.
Namun tidak terdapat hubungan yang bermakna antara jenis kelamin dengan kejadian depresi. Hasil yang didapatkan pada penelitian ini bisa saja terjadi dikarenakan responden perempuan lebih banyak dibandingkan responden lelaki. ${ }^{7}$

Hasil penelitian menunjukkan bahwa responden terbanyak ialah responden yang termasuk kategori umur 26-35 tahun sebanyak 9 orang (30,0\%) dan responden dengan kategori usia 17-25 tahun sebanyak 2 orang $(6,7 \%)$ dan 56-65 tahun sebanyak 8 orang (26,7\%). Berdasarkan data yang diolah, menunjukan bahwa mayoritas responden mengalami depresi sedang pada usia 26-35 tahun yaitu sebanyak 6 orang (20\%) dan sebanyak 2 orang (6,7\%) mengalami depresi berat pada usia 26-35 tahun. Hal ini juga dibenarkan oleh Kaplan dan Sadock, mereka mengatakan bahwa 50\% usia diantara 20-50 tahun lebih rentan terhadap gangguan depresi. ${ }^{8}$

Berdasarkan hasil yang dikumpulkan dari tiap-tiap responden juga menunjukan bahwa tingkat pendidikan terakhir responden terbanyak ialah SMA yaitu 22 orang $(73,3 \%)$ dan responden yang berpendidikan SD sebanyak 2 orang (6,7\%) dan responden mengalami depresi sedang pada tingkat pendidikan SMA yaitu sebanyak 12 orang (40\%) dan sebanyak 3 orang $(10 \%)$ yang mengalami depresi berat pada tingkat SMA. Hal ini tidak sesuai dengan penelitian yang dilakukan oleh Mukadder dalam Wijaya yang menyatakan bahwa makin rendah tingkat pendidikan pasien makin tinggi skor BDI-nya. ${ }^{9}$

Dari hasil data yang sudah diolah juga menunjukan bahwa sebanyak 17 orang (56,7\%) tidak bekerja dan 13 orang (43,3\%) bekerja. Tabel 1 menunjukan bahwa responden yang tidak bekerja lebih banyak mengalami depresi sedang, yaitu sebanyak 8 orang (26,7\%) dan sebanyak 4 orang $(13,3 \%)$ yang tidak bekerja mengalami depresi berat.

Penelitian yang dilakukan oleh wijaya juga mengatakan dengan tidak adanya pekerjaan pada individu hal ini bisa saja mengakibatkan seseorang mengalami 
gangguan depresi, dikarenakan tidak adanya kegiatan yang dikerjakan yang dapat mengalihkan dari rasa tidak nyaman. ${ }^{9}$

Responden yang berpartisipasi menunjukkan hampir semua berasal dari suku Minahasa yang merupakan mayoritas suku di kota Manado. Terdapat 20 orang (66,7\%) berasal dari daerah luar Manado, Sangihe dan Cina masing-masing 4 orang (13,3\%).

Hampir semua responden, menunjukan bahwa agama Kristen merupakan kepercayaan yang paling banyak dianut oleh responden, dikarenakan mayoritas suku minahasa adalah beragama Kristen, hasil data menunjukan yaitu sebanyak 21 orang $(70,0 \%)$ yang beragama Kristen, diikuti dengan agama Islam (20\%), dan agama katolik (10\%). Agama Kristen memang merupakan agama yang paling banyak dianut oleh masyarakat Sulawesi utara berdasarkan data demografi agama tahun 2010 yaitu $63,60 \%$ penduduk Sulawesi utara beragama Kristen.

\section{SIMPULAN}

Berdasarkan hasil penelitian yang telah dilakukan terhadap 30 responden dapat disimpulkan bahwa responden yang paling banyak terlibat dalam penelitian ialah responden yang berjenis kelamin perempuan. Responden yang berada dalam kategori usia 26-35 juga merupakan responden terbanyak dalam penelitian.

Responden terbanyak beragama Kristen dan mayoritas responden berprofesi sebagai ibu rumah tangga atau tidak bekerja. Tingkat depresi yang paling banyak dialami oleh responden ialah depresi sedang berjumlah 15 orang sedangkan yang paling sedikit ialah responden yang tidak memiliki gangguan depresi atau normal sebanyak 3 orang. 6 .

Setelah banjir bandang, ekonomi seluruh responden rata-rata mengalami penurunan, keadaan ekonomi yang menurun ini mengakibatkan warga daerah tikala ares lingkungan 3 mempunyai standar ekonomi yang rendah.

Secara logika jika curah hujan pada sekarang ini tidak kunjung berkurang dan tetap tidak mendapat perhatian yang serius dari pemerintah maka akan ditemukan sekian banyak dari masyarakat yang terkena banjir bandang akan mengalami gangguan depresi berat.

\section{SARAN}

Penelitian ini merupakan penelitian dasar yang menggambarkan tentang tingkat depresi pada warga korban Banjir Bandang di kelurahan Tikala Ares kota Manado. Penelitian lanjutan dibutuhkan untuk membahas lebih dalam lagi menyangkut tingkat depresi pada warga korban banjir bandang sebelum dan setelah banjir bandang.

Disarankan Pemerintah kota Manado untuk meningkatkan tingkat kepedulian terhadap masyarakat yang terkena dampak kerusakan akibat banjir bandang di kota Manado dan menyediakan jasa Psikiater bagi masyarakat yang tinggal di daerah rawan banjir yang rentan mengalami gangguan depresi.

\section{DAFTAR PUSTAKA}

1. Budiman C. Ilmu Kedokteran Pencegahan dan Komunitas. Husny M, Windriya Kerta N, editors. Jakarta: EGC, 2006; p. 5-6.

2. Atuti WM, Sumarwati $M$, Seiono $T$. Pengaruh terapi kognitif restrukturisasi terhadap penurunan skor depresi pada pasien gangguan jiwa. J Keperawatan Soedirman. 2010;5(3):164-5.

3. Dewi FIR, Djoenaina V, Melisa. Hubungan antara resiliensi dengan depresi pada perempuan pasca mastektomi. J Psikologi. 2004;2(2): 108-12.

4. Nilasari S. Positive psychotherapy untuk menurunkan tingkat depresi. J Sains dan Praktik Psikologi. 2013;I(2):17989.

5. Carolina M, Manalip H, Sangkertadi. Upaya adaptasi elemen bangunan untuk mitigasi bencana banjir bandang. J Media Matrasain. 2014;11 (2):48-52.

6. Arista A. Hubungan antara karakteritik 
umur, jenis kelamin, pendidikan, pekerjaan dengan timbulnya depresi. Jember: Fakultas Kedokteran UJ; 2007.

7. Kaplan HI, Sadock BJ, Grebb JA. Sinopsis Psikiatri : Ilmu pengetahuan perilaku psikiatri klinis Jilid satu. Made Wiguna S, editors. Jakarta:
Bina Rupa Aksara, 2010; p. 791-839.

8. Elvira DS, Hadisukanto G. Buku ajar psikiatri (1st ed). Jakarta: Badan Penerbit FKUI, 2010; p. 209-22.

9. Wijaya A. Kualitas hidup pasien penyakit ginjal kronik yang menjalani hemodialisis dan mengalami depresi. Jakarta: FKUI;2005. 